\title{
Physical Characteristics and Technology of Glass Foam from Waste Cathode Ray Tube Glass
}

\author{
G. Mucsi, ${ }^{1}$ B. Csőke, ${ }^{1}$ M. Kertész, ${ }^{1}$ and L. Hoffmann ${ }^{2}$ \\ ${ }^{1}$ Institute of Raw Material Preparation and Environmental Processing, University of Miskolc, Miskolc Egyetemváros 3515, Hungary \\ ${ }^{2}$ Geofil Co. Ltd., Alugyári utca 1, Tatabánya 2800, Hungary
}

Correspondence should be addressed to G. Mucsi; ejtmucsi@uni-miskolc.hu

Received 30 November 2012; Revised 17 February 2013; Accepted 18 February 2013

Academic Editor: John W. Gillespie

Copyright (c) 2013 G. Mucsi et al. This is an open access article distributed under the Creative Commons Attribution License, which permits unrestricted use, distribution, and reproduction in any medium, provided the original work is properly cited.

\begin{abstract}
This paper deals with the laboratory investigation of cathode-ray-tube- (CRT-) glass-based glass foam, the so-called "GeofilBubbles" which can be applied in many fields, mainly in the construction industry (lightweight concrete aggregate, thermal and sound insulation, etc.). In this study, the main process engineering material properties of raw materials, such as particle size distribution, moisture content, density, and specific surface area, are shown. Then, the preparation of raw cathode ray tube glass waste is presented including the following steps: crushing, grinding, mixing, heat curing, coating, and sintering. Experiments were carried out to optimize process circumstances. Effects of sintering conditions-such as temperature, residence time, and particle size fraction of green pellet—on the mechanical stability and particle density of glass foam particles were investigated. The mechanical stability (abrasion resistance) was tested by abrasion test in a Deval drum. Furthermore, the cell structure was examined with optical microscopy and SEM. We found that it was possible to produce foam glass (with proper mechanical stability and particle density) from CRT glass. The material characteristics of the final product strongly depend on the sintering conditions. Optimum conditions were determined: particle size fraction was found to be $4-6 \mathrm{~mm}$, temperature $800^{\circ} \mathrm{C}$, and residence time $7.5 \mathrm{~min}$.
\end{abstract}

\section{Introduction}

The corresponding law regulation which came into force in 2004 divides the electric and electronic equipment into ten categories. Those categories in which cathode ray tube (CRT) is mainly applied (consumer electronics and IT) form a significant fraction (nearly $30 \%$ ) of the electronic waste.

Recycling of the scrap CRT poses a special problem. There is no public demand for CRT devices any more; accordingly there is no CRT recycling capacity in Europe and there are barely recycling opportunities outside of Europe. Managing this problem is critical from the viewpoint of functional WEEE treatment systems. The volume rate of the waste CRT devices based on the estimations of Bay Zoltán Nonprofit Ltd.: in the IT category is about $31 \%$ and in the consumer electronic category is about $41 \%$ of the total annual amount.

There is no demand for raw material glass with lead content because there is no CRT manufacturer in Europe. Recycling of CRTs is great problem all over Europe as the arising volume of the CRT glass waste is 400000 tons annually and only few practical and economic solutions are found for recycling.

There are two kinds of cathode ray tubes: black and white (or monochrome) and color. These two types of CRTs are made of different glass $[1,2]$. The neck $(\sim 1 \mathrm{wt} \%)$ and funnel ( $\sim 33 \mathrm{wt} \%)$ glass constitute the back part of the CRT (hidden inside the monitor or TV set). The front part, usually known as the panel ( $66 \mathrm{wt} \%)$, is made of a bariumstrontium glass that is free of lead since $1995[3,4]$ and is very homogeneous and thick. These three components are usually joined together with a solder glass called frit, which contains $85 \mathrm{wt} \%$ lead. The neck glass of cathode-ray tube glass is a lead-rich silicate glass containing up to $40 \mathrm{wt} \% \mathrm{PbO}$, which envelopes the electron gun. The lead content of funnel glass is lower than that of neck glass $(\sim 20-25 \mathrm{wt} \%$ of $\mathrm{PbO})$. The addition of lead to this glass is essential for absorbing the UV and $\mathrm{X}$-ray radiation produced by the electron gun in CRTs. In the panel glass of color CRTs, however, barium and strontium are used instead of lead because this glass needs to be colorless $[5,6]$. 
Méar et al. [5, 6] determined the chemical composition, densities, coefficient of thermal expansion, and the glass transition temperature of waste cathode ray tube glass originated from Asian or South-Asian manufacturers (including Japan, Taiwan, and Korea). They found that color CRTs are made with two different glass formulations, one for the panel and one for the funnel, in contrast to black and white CRTs, which use only one formulation.

There are several technologies for the utilization of CRT glass in the literature. Some of them are shown below. For example, Chen et al. [7] investigated the recovery of metallic lead from the funnel glass and the preparation of foam glass. In the pyrovacuum process, lead in the funnel glass was firstly detached and changed to $\mathrm{PbO}$, then reduced and evaporated, and was recovered in the form of pure metal with a purity of $99.3 \%$. The maximum lead removal rate reached $98.6 \%$ when the temperature, pressure, carbon adding amount, and holding time were $1000^{\circ} \mathrm{C}, 1000 \mathrm{~Pa}, 9 \%$, and $4 \mathrm{~h}$, respectively. The produced porous glass was environmentally acceptable for construction applications.

Envirocycle (a US company) developed a process [8] to recycle all glasses contained in CRTs; this process includes cleaning and sorting of the glass. The product obtained is used for the manufacture of new CRT glass. Some industries have used pulverized glass from CRTs in smelting processes as slagging material instead of sand or slag.

Méar et al. [5, 6] examined the effects on foam glass microstructures by varying the elaboration parameters, reaction time, temperature, and composition with scanning electron microscopy. Foam glass was prepared using various concentrations of $\mathrm{SiC}$ or $\mathrm{TiN}$ as the reducing agent for various temperatures $\left(750,850\right.$, and $\left.950^{\circ} \mathrm{C}\right)$ and reaction times $(30$, 60 , and $90 \mathrm{~min}$ ). They demonstrated that increases in the three synthesis parameters strongly affect the microstructures of the foam glasses. Increases in cell diameter lead to large reductions in mechanical resistance. Further, the reduction of lead oxide content in these glasses also increases, as shown by the increase in metal lead formation in the form of droplets (bubbles) on the cell surface.

Kim et al. [9] developed a method producing a concrete composite crosslinked with minute amounts of biopolymers and a cross-linking agent. Commercially available microbial biopolymers of xanthan gum and guar gum were used. This CRT-biopolymer-concrete (CBC) composite showed higher compressive strength than the standard concrete and a considerable decrease in lead leachability (good encapsulation of CRT wastes) as measured by standard USEPA methods.

There are technologies for extracting metal oxides from glass. One way is smelting to reduce the metal oxides to metal by melting the glass waste in reducing conditions using reactants (carbon, aluminium). Another way is the electrolytic separation by applying a voltage across a molten bath of glass [10]. Furthermore, the CRT glass can be utilized as a substitute for sand in the smelting process, the generated slag can then be used as road aggregate. Additionally, it can be used in the ceramics and building products industry (bricks and tiles or as a flux). To be used in this way, the glass must be free from contamination and ground to fine size.
According to Seo et al. [11], possible application technologies of CRT panel waste are cement brick, clay brick, and glass wool. Also, application technologies of funnel are glazing and lead smelting. As results of cement brick and clay brick in labscale tests, the entire samples satisfied the Korean Standard.

A pellet product under the name "Geofil-Bubbles" [12] from industrial waste material of high glass content is manufactured by recycling technology (Hungarian patent). The waste glass materials may have organic and inorganic impurities. Waste materials of high glass content are ground to appropriate particle fineness. The pelletization process is carried out by adding melting point reducer and viscosity modifying agents. The green pellet is then heat cured and coated to decrease its water absorbing capability. Sintering is carried out in a rotary furnace. The product is a lightweight artificial gravel with a diameter of 1 to $25 \mathrm{~mm}$ having primarily thermal and sound insulating properties with good bonding capability if embedded in gypsum, cement, or resin matrix.

Józsa and Nemes [13] studied different types of "GeofilBubbles" manufactured of waste glass using recycling technology which were tested at the Department of Construction Materials and Engineering Geology, Budapest University of Technology and Economics as lightweight aggregate for concrete (LWAC). This new material is alkali resistant (according to DAfStb 1986). Similar compressive strengths can be reached by LWAC as in case of normal-weight concrete (NWC). Even higher strength can be reached by additional silica fume or cement or by lower water/cement ratio. Admixtures are required to have appropriate workability. 2day compressive strengths of LWAC were $75 \%$ of that of 28 days.

In the previous patent and study $[12,13]$, the application of the Geofil bubbles in the construction industry was investigated. However, the present paper shows the results regarding laboratory scale preparation of the above-mentioned product from process engineering point of view. The general aim of this research is to develop the "Geofil-Bubbles" technology for CRT-glass-based foam for industrial applications, mainly construction industrial use. The goal of this paper is to show a brief overview of cathode ray tube glass processing possibilities and to demonstrate the experimental results carried out at the University of Miskolc in order to optimize the pelleting and the sintering processes.

\section{Material Properties}

Firstly, the received dismantled CRT waste of black and white (monochrome) and color TVs were prepared for laboratory tests. The waste glass was first crushed with a jaw crusher and then milled by a rolls mill. Physical material properties were measured in the waste glass and other raw materials (bentonite, limestone, dolomite, and alumina), for example, particle size distribution, density, moisture content, and grindability (Hardgrove Grindability Index and calculated Bond-Work Index).

The particle size distribution of the ground material was measured by HORIBA LA-950V2 laser diffraction particle 
TABLE 1: Chemical composition of the raw materials (additives).

\begin{tabular}{|c|c|c|c|c|c|c|c|c|c|c|c|c|c|c|c|c|c|}
\hline Name & $\mathrm{SiO}_{2}$ & $\mathrm{TiO}_{2}$ & $\mathrm{Al}_{2} \mathrm{O}_{3}$ & $\mathrm{FeO}$ & $\mathrm{Fe}_{2} \mathrm{O}_{3}$ & $\mathrm{MnO}$ & $\mathrm{CaO}$ & $\mathrm{MgO}$ & $\begin{array}{c}\mathrm{Na}_{2} \mathrm{O} \\
\%\end{array}$ & $\mathrm{~K}_{2} \mathrm{O}$ & $-\mathrm{H}_{2} \mathrm{O}$ & $+\mathrm{H}_{2} \mathrm{O}$ & $\mathrm{CO}_{2}$ & $\mathrm{P}_{2} \mathrm{O}_{5}$ & $\mathrm{SO}_{3}$ & $\mathrm{BaO}$ & $\mathrm{SrO}$ \\
\hline Limestone & 2.01 & $<0.02$ & 0.465 & $<0.02$ & 0.202 & 0.009 & 54.9 & 0.523 & 0.046 & $<0.2$ & 0.05 & 0.05 & 41.6 & $<0.15$ & $<0.15$ & $<0.005$ & 0.037 \\
\hline Dolomite & 0.326 & $<0.02$ & 0.151 & $<0.02$ & 0.040 & $<0.003$ & 30.2 & 21.9 & 0.070 & $<0.2$ & $<0.01$ & 0.10 & 46.7 & $<0.15$ & $<0.15$ & $<0.005$ & 0.011 \\
\hline $\begin{array}{l}\text { Na-bentonite } \\
\text { (Egyházaskesző) }\end{array}$ & 44.1 & 2.02 & 15.6 & 0.086 & 9.11 & 0.081 & 1.92 & 2.03 & 3.34 & 0.607 & 9.43 & 7.89 & 2.42 & 0.277 & $<0.15$ & 0.050 & 0.017 \\
\hline $\begin{array}{l}\text { Na-bentonite } \\
\text { (Pétervására) }\end{array}$ & 62.6 & 0.267 & 12.7 & 0.131 & 2.33 & 0.056 & 1.61 & 0.764 & 1.06 & 1.44 & 7.75 & 6.78 & 0.563 & $<0.15$ & $<0.15$ & 0.070 & 0.014 \\
\hline Ca-bentonite & 44.1 & 2.09 & 16.1 & 0.114 & 9.32 & 0.043 & 1.83 & 2.15 & 0.439 & 0.709 & 8.04 & 10.2 & 0.492 & 0.333 & $<0.15$ & 0.045 & 0.017 \\
\hline Corundum & 0.128 & $<0.02$ & 99.3 & $<0.02$ & 0.053 & 0.004 & 0.033 & $<0.15$ & 0.264 & $<0.2$ & 0.03 & 0.02 & $<0.02$ & $<0.15$ & $<0.15$ & 0.006 & 0.002 \\
\hline
\end{tabular}

TABLE 2: Phase composition of the raw materials (additives).

\begin{tabular}{|c|c|c|c|c|c|c|}
\hline Sample & Corundum & Na-bentonite $(\mathrm{P})$ & Ca-bentonite & Na-bentonite (E) & Limestone & Dolomite \\
\hline Montmorillonite & & 47 & 39 & 73 & & \\
\hline Illit-montmorillonite & & & 14 & & & \\
\hline Illite & & 7 & 18 & & & \\
\hline Kaolonite & & & & 3 & & \\
\hline Quartz & & 6 & 5 & 6 & 2 & \\
\hline Plagioclase & & 5 & & & & \\
\hline Calcite & & 3 & 7 & 4 & 96 & \\
\hline Dolomite & & & & & 2 & 100 \\
\hline Anatase & & & & 3 & & \\
\hline Corundum & 98 & & & & & \\
\hline Diaoyudaoit & 2 & & & & & \\
\hline Clinoptilolite & & 2 & & & & \\
\hline Cristobalit & & 21 & & & & \\
\hline Amorphous & & 9 & 17 & 11 & & \\
\hline
\end{tabular}

size analyzer in wet mode using distilled water as dispersing media and sodium-pyrophosphate as dispersing agent applying the Mie theory as evaluation method. The density was determined by pycnometer method using alcohol as media. Moisture content was measured in drying oven at $105^{\circ} \mathrm{C}$ until constant mass. The drying time required to achieve constant mass varied depending on the type of the material, that is, bentonite, limestone, and corundum. In most cases, an overnight (12-16 h) drying period was sufficient.

The materials used were as follows: foaming agents were dolomite and limestone, pelleting agents were $\mathrm{Na}$-bentonites and Ca-bentonite, additionally $\mathrm{Al}_{2} \mathrm{O}_{3}$ was used to avoid aggregation of melted particles.

The chemical (oxidic) and phase composition of the additives were determined. Oxidic composition was measured by $\mathrm{LiBO}_{2}$ extraction. The results can be seen in Table 1.

Additionally, the mineral composition of the materials was determined by Philips PW 1730 XRD apparatus (Table 2). Corundum, limestone, and dolomite have relatively homogeneous mineral composition. However, in the three bentonite samples montmorillonite, illite, kaolinite, quartz, plagioclase, calcite, clinoptilolite, and cristobalite were detected as main minerals. Furthermore, the amorphous content of bentonite samples was 9,11 , and $17 \%$.
For the characterization of the grindability of minerals different grindability indices-Bond Work Index $\left(W_{i}\right)$, Hardgrove Grindability Index (HGI), or Zeisel-Specific Grindability $\left(W_{t}\right)$-are used. Generally, Bond Work Index for mill dimensioning and controlling is measured by grinding the feed material of $<3.36 \mathrm{~mm}$ particle size under standardized conditions in a so-called Bond mill $(D \times L=305 \mathrm{~mm} \times$ $305 \mathrm{~mm}$ ). Bond method simulates closed-circuit grinding which is carried out in sections until the establishment of equilibrium. From the evaluation of laboratory and industrial experiments, the work index can be determined as follows [14]:

$$
W_{i B}=\frac{4.9}{x_{\max }^{0.23} G^{0.82}\left(1 / \sqrt{x_{80}}-1 / \sqrt{X_{80}}\right)},
$$

where $W_{i B}=$ Bond laboratory ball work index $(\mathrm{kWh} / \mathrm{t}) ; x_{\max }$ $=$ max. particle size of the product $(<106 \mu \mathrm{m})$ in $\mu \mathrm{m} ; G=$ net grams of sieve undersize per mill revolution $(\mathrm{g} / \mathrm{rev}) ; x_{80}=$ $80 \%$ passing size of the product in $\mu \mathrm{m} ; X_{80}=80 \%$ passing size of the feed in $\mu \mathrm{m}$. 
TABLE 3: Density and moisture content of the raw materials.

\begin{tabular}{|c|c|c|c|c|c|c|c|}
\hline Sample & Limestone & $\mathrm{Al}_{2} \mathrm{O}_{3}$ & Dolo-mite & Na-bentonite 1 & Na-bentonite 2 & Ca-bentonite & Glass \\
\hline Density, $\mathrm{kg} / \mathrm{m}^{3}$ & 2719.6 & 3916.2 & 2610.8 & 2192.4 & 2291.7 & 2340.5 & 2819.9 \\
\hline Moisture content, \% & 0.19 & 0.39 & 0.34 & 7.30 & 8.16 & 5.72 & 0.52 \\
\hline
\end{tabular}

TABLE 4: Grindability indices of the CRT glass parts.

\begin{tabular}{lcccc}
\hline & Monoch. front & Monoch. funnel & Color front & Color funnel \\
\hline HGI & 48.83 & 50.28 & 46.54 & 51.81 \\
Bond- work index, kWh/t & 17.95 & 17.51 & 18.65 & 17.08 \\
\hline
\end{tabular}

The grindability was determined using the conventional Hardgrove test method where the HGI is calculated by the following formula:

$$
\mathrm{HGI}=13+6.93 m_{74}
$$

where HGI is the Hardgrove Grindability Index, and $m_{74}$ is the mass of product finer $74 \mu \mathrm{m}$ in $\mathrm{g}$.

Using the HGI value the Bond Work Index can be calculated by the following equation:

$$
W_{i B}^{H}=\frac{468}{\mathrm{HGI}^{0.82}} .
$$

The particle size distribution was measured by dry sieving and Fritsch Analysette 22 type laser size analyzer; the curves are given in Figure 1.

The raw material properties are found in Tables 3 and 4 . From these data, it can be established that moisture content was very low $(<1 \%)$ except of the bentonite samples $(5.72-$ $8.16 \%)$. Furthermore, the grindability of the front glass was a bit higher than that of the funnel glass in both glass types: monochrome and color. It means that previous ones need more specific grinding energy than latter ones to reach the same material fineness. The grindability has an important goal from a technological point of view when processing plant is designed.

\section{Experimental}

In the research work, we focused on the product so called "Geofil-Bubbles." As it was mentioned before, this is a spherical shape glass foam which can be used as heat and sound insulating material (high porosity). One key step of the technology is the pelletization of the ground raw materials. For this purpose, laboratory experiments were performed to determine the optimal conditions for producing pellets with good mechanical stability. Before this step, the raw glass waste was ground in a laboratory ball mill to reach the appropriate fineness, and then additives-bentonite and limestone-were fed into the mill to homogenise them (intergrinding).

The green pellets were manufactured with a pelleting plate in batch mode. After preparing the green pellets, they were dried in a drying cabinet at $105^{\circ} \mathrm{C}$ for 2 hours. The mechanical stability (resistance of pellets to degradation by abrasion) of the dried pellets was tested with a conventional Deval drum $(\varnothing 210 \times 340 \mathrm{~mm})$ apparatus. Generally, the
Deval Attrition Test Machine is used for the determination of resistance of aggregates to wear by abrasion. It consists of a hollow cylinder closed at one end and provided with tight fitting covers at the either end. The cylinder is mounted on a shaft at an angle of 30 degrees with the axis of rotation of the shaft. The shaft rotates at 30-33 r.p.m. through a reduction gear operated by a motor and is provided with a revolution counter.

In this test series, the standard method was modified to be able for fast test. A given amount ( 25 gramms) of pellet was fed into the Deval drum, the residence time was $10 \mathrm{~min}(300$ revolutions), and then the particles were sieved to determine the mass fraction of the material finer than $1 \mathrm{~mm}$. The feed of the test was the fraction of green pellets coarser than $2.5 \mathrm{~mm}$. In this way, the mass fracion of particles finer than $1 \mathrm{~mm}-$ produced in the drum-characterizes the abrasion loss (rate of abrasion) of pellets in dry circumstances.

The abrasion was calculated using following formula:

$$
\Delta m_{\mathrm{abr}}=\frac{m_{\text {fine }}}{m_{\text {feed }}} 100[\%],
$$

where $\Delta m_{\text {abr }}$ is the rate of abrasion in $\%, m_{\text {fine }}$ is the weight of material $<1 \mathrm{~mm}$ in $\mathrm{g}$, and $m_{\text {feed }}$ is the feed weight of Deval test (25 g).

The variable parameters for the pelleting experiments were as follows: (1) concentration of Na bentonite, (2) water content, and (3) revolution of the pelleting plate.

The variable parameters of sintering experiments were (1) pellet size, (2) sintering temperature, and (3) residence time. In order to monitor the behaviour of particles with different size during the sintering process, the previously prepared dried pellets were separated into size fractions, that is, 2$4 \mathrm{~mm}, 4-6 \mathrm{~mm}$, and 6-8 $\mathrm{mm}$. After sieving, each size fraction of the material was sintered in a furnace at $600,650,700$, $750,800,850$, and $900^{\circ} \mathrm{C}$. Additionally, the residence time was decided to be $5,7.5$, and $10 \mathrm{~min}$. After sintering the glass foam particles were cooled down at room temperature and the abrasion loss (same way as described before) and particle density was determined. For monitoring the foam structure, optical microscopy measurements were performed with Zeiss Imager.M2m apparatus.

\section{Results}

4.1. Pelleting Results. In the first experimental series, the effect of the concentration of bentonite was investigated in 


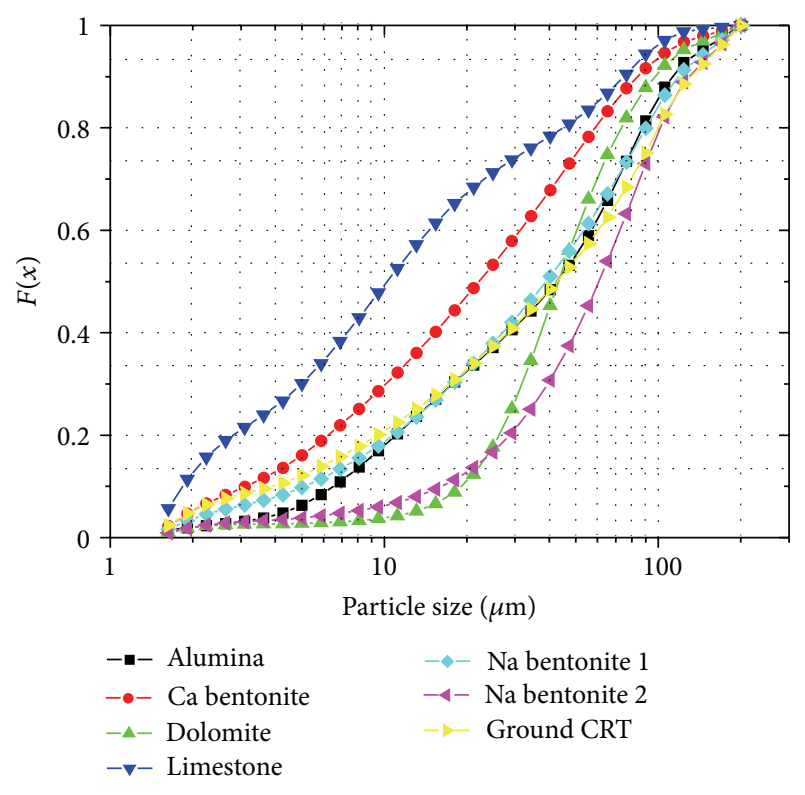

FIGURE 1: Particle size distribution of raw materials (treated).

the dosage of $0,2.5,5,7.5$, and $10 \%$ for the mass of glass. The water content and the revolution of the plate were constant, $20 \%$ and $40 \%$ of the critical speed, respectively.

The mechanical stability of the pellets can be seen in Figure 2. The most significant difference (15\%) was found between 0 and $2.5 \mathrm{~m} / \mathrm{m} \%$ bentonite content; after this point a slight decrease can be found in the rate of abrasion.

In the second step, the effect of the speed of the plate was examined with $40,50,60$, and $70 \%$ of the critical speed. It was observed that increasing the pelleting plate's speed caused no evident changes in the mass fraction of fines. However, the shape of the particles changed significantly, that is, more spherical shapes were achieved at higher speeds [15].

In the third series, the effect of the water content was studied with $17.5,20$, and $22.5 \mathrm{~m} / \mathrm{m} \%$ water dosage. According to our results, the optimal water dosage was $20 \mathrm{~m} / \mathrm{m} \%$. Pellets with lower water content $(17.5 \%)$ became weak due to the insufficient capillary forces. In contrast to this, the higher water content resulted better throughput $(\mathrm{kg} / \mathrm{h})$ of the valuable size fraction. At the same time, the particles were generated with deformed shape and coarser diameter, furthermore, the material loss increased due to the sticking of the powder to the wall of the apparatus [15].

Based on our study, it can be concluded that using the above presented raw materials under the suitable conditions, pellets with appropriate mechanical stability can be produced. Optimal pelleting parameters were determined: bentonite concentration was found to be $2.5-7.5 \mathrm{~m} / \mathrm{m} \%$, plate speed was $60 \%$ of the critical speed, and water content (which was the most sensitive parameter) was $20 \mathrm{~m} / \mathrm{m} \%$.

\subsection{Results of Systematic Sintering Experiments}

4.2.1. Particle Density. At the temperature at which the glass primary particles become soft enough to cohere, the agent

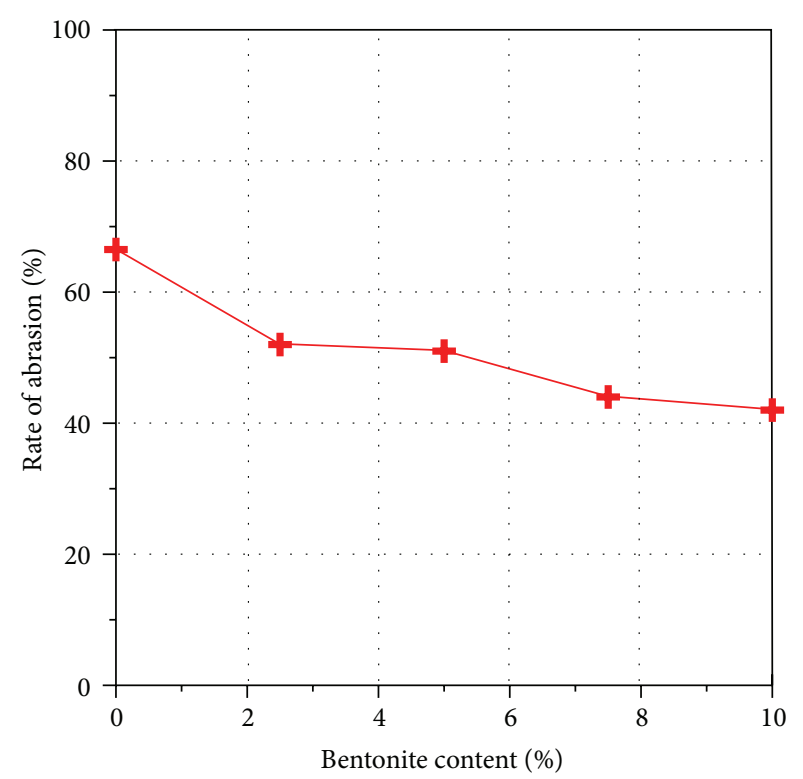

FIGURE 2: Mechanical stability of pellets as function of bentonite concentration.

(calcite) gives off a gas $\left(\mathrm{CO}_{2}\right)$ that is entrapped in the glass and forms the closed-cell structure that remains after cooling. The main effect of $\mathrm{CO}_{2}$ gas generation in the glass pellet during sintering is the increase of porosity and parallelly the decrease of particle density.

The foaming of CRT glasses by $\mathrm{CaCO}_{3}$ thermal decomposition does not depend on oxidation/reduction processes, which could cause the precipitation of metallic colloids by reduction of easily reducible oxides like $\mathrm{PbO}$. Moreover, the relatively low temperature required (CRT glasses have a low softening point) prevents the volatilization of the $\mathrm{PbO}$ [16].

The change of particle density is described in the following part as function of residence time and temperature depending on pellet size. The particle density of the three different size fractions is plotted as function of temperature in Figure 3.

The initial particle density of dried green pellets was found to be

(i) fraction $2-4 \mathrm{~mm}: \rho_{p}=2226.72 \mathrm{~kg} / \mathrm{m}^{3}$;

(ii) fraction $4-6 \mathrm{~mm}: \rho_{p}=1905.54 \mathrm{~kg} / \mathrm{m}^{3}$;

(iii) fraction $6-8 \mathrm{~mm}: \rho_{p}=2054.17 \mathrm{~kg} / \mathrm{m}^{3}$.

The sintering temperature has great influence on the particle density of the product. However, Figure 3 shows that the temperature has no significant effect on the density of the pellet at any size faction in the temperature range from 600 to $750^{\circ} \mathrm{C}$ independently from the residence time. Fluctuation of particle density can be detected in a wide range from $1700 \mathrm{~kg} / \mathrm{m}^{3}$ up to $2500 \mathrm{~kg} / \mathrm{m}^{3}$ (instable section). Therefore, these temperatures are insufficient for producing foam structure. However, slight increase was found in the above temperature interval if average values are taken into account. Probably it can be explained by the phenomenon 


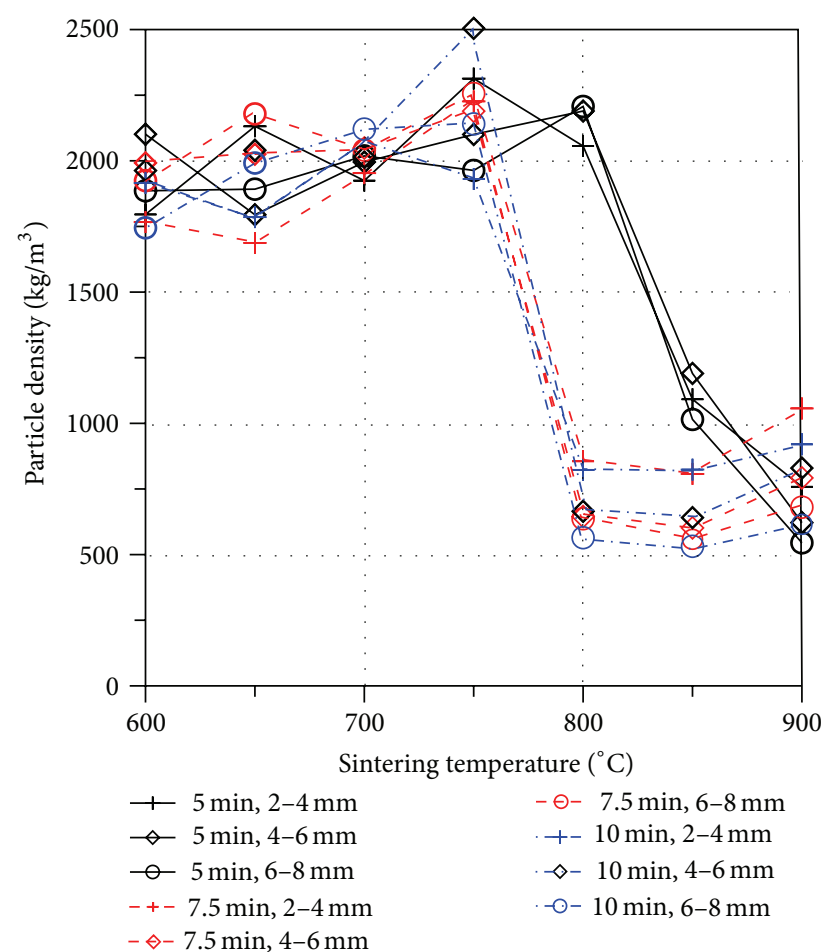

FIGURE 3: Influence of temperature on particle density.

that glass melting starting prior to carbon dioxide release. In this way, the density starts to increase and when the gas generation starting (about $800^{\circ} \mathrm{C}$ ) the density decreased suddenly.

Contrary to the above written phenomena, a significant decrease of particle density was observed at $800^{\circ} \mathrm{C}$ at 7.5 and 10 -minute time, this decrease appears at 850 and $900^{\circ} \mathrm{C}$ even at $5 \mathrm{~min}$ residence time.

The reason behind density decrease can be explained with the phenomenon of $\mathrm{CO}_{2}$ generation due to the calcination of the limestone (foaming agent) at higher than $750^{\circ} \mathrm{C}$. The gas expands, which results in a cellular structure. Parallelly, the glass reaches its softening point and becomes melted avoiding the escape of gas from the particle resulting in a porous structure, foam-like particle with high strength. Another effect of the sintering process that through $\mathrm{CO}_{2}$ gas forms cells, the diameter of the particle becomes at least two times higher.

Glass viscosity, the foaming temperature, and residence time are strongly related. The optimum foaming temperature must be selected by considering, on the one hand, the maximum foam stability, which is controlled by viscosity, and, on the other hand, the internal cell structure, characterized by homogeneous and regular shape and size of the pores and by the minimum thickness of their separating walls [17]. If the foaming temperature is high, the melt viscosity is too low, and controlling the structure becomes difficult because bubbles rise to the top of the mold (as in fining of glass). On the contrary, if the temperature is low, the glass viscosity is high, and gas expansion is difficult and little increase in volume occurs. In this case, the formation of the

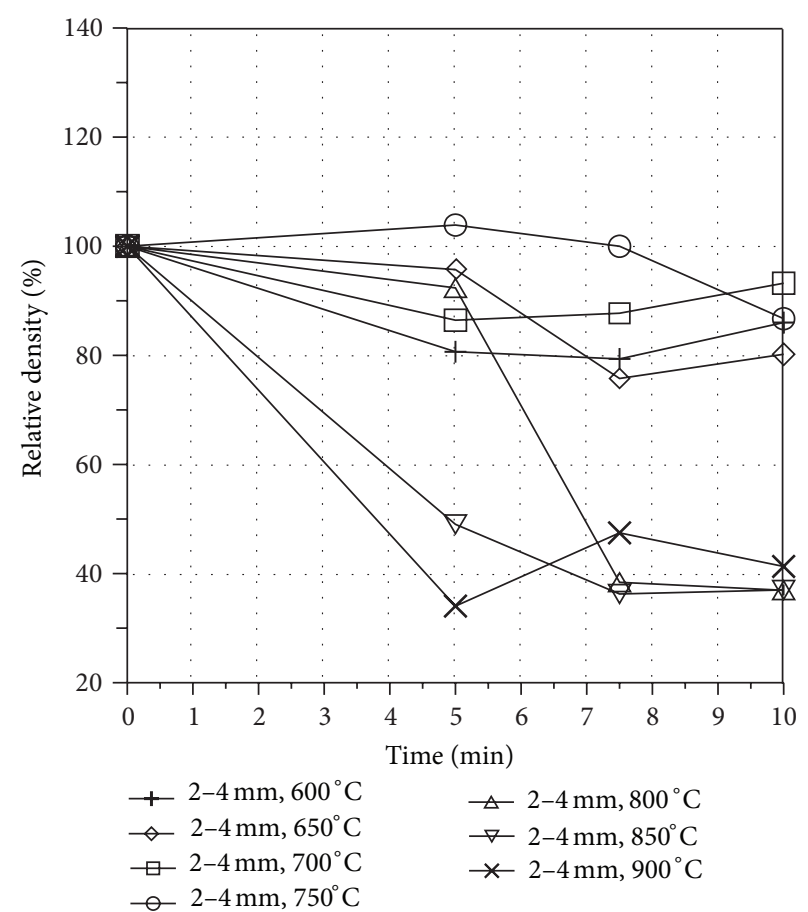

FIGURE 4: Change of relative density as function of residence time in case of size fraction $2-4 \mathrm{~mm}$.

separating walls does not go to completion, and residual open porosity results, so that water absorption of the glass foam in service increases. During the period of gas release, the density continuously decreases down to a minimum value. When this stage finishes, a gradual process of destruction and collapse of the foam by coalescence of the pores begins. Thus, the surface energy of the system is decreased by the reduction of the specific surface area of the walls of the cells. This process leads to a new increase in density [18]. Hence, it is necessary to calculate precisely the time of heat treatment and to remove the glass foam from the hot zone prior to the beginning of the coalescence process.

According to the literature, the most convenient viscosity range for optimizing the foaming process for development of maximum of porosity and minimum apparent (particle) density is 105 to $103 \mathrm{~Pa} \cdot \mathrm{s}$ [16].

To compare the effect of residence time on the density of particles for every size fractions, relative density was calculated for each case. It was determined by the ratio of final density and initial value. These curves can be seen in Figures 4-6. The most substantial density decrease was reached at $900^{\circ} \mathrm{C}(5 \mathrm{~min})$, where 34,37 , and $27 \%$ of the original density was reached at 2-4 mm, $4-6 \mathrm{~mm}$, and $6-8 \mathrm{~mm}$, respectively. However, further increase of time at this temperature results in higher density, the material starts to be more compact with less porous structure because the gas can escape from the particle. It can be explained by the fact that the viscosity of the melted glass probably diminishes at $900^{\circ} \mathrm{C}$, and there is enough time for this phenomenon to be taking place.

In the interval of $600-750^{\circ} \mathrm{C}$ sintering temperature, only slight decrease (maximum 20\%) was achieved even at 7.5 


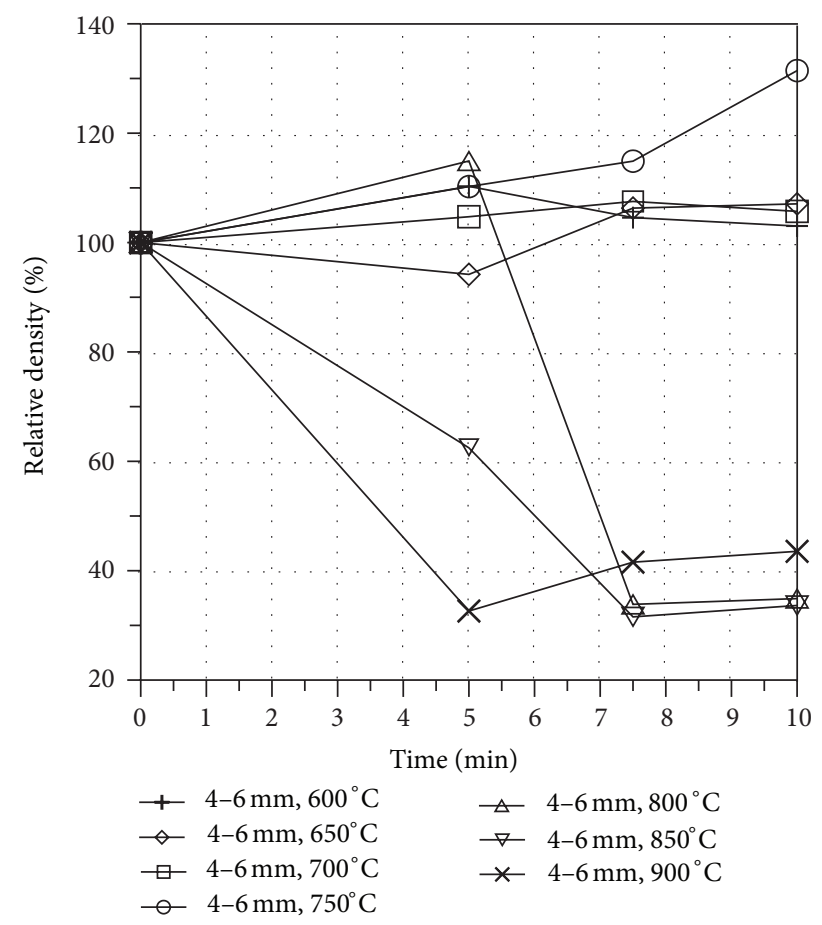

FIGURE 5: Change of relative density as function of residence time in case of size fraction $4-6 \mathrm{~mm}$.

and $10 \mathrm{~min}$ residence time in the $2-4 \mathrm{~mm}$ fraction (Figure 4). Only exception was at $750^{\circ} \mathrm{C}$ where the particle density first increased by $4 \%$ at $5 \mathrm{~min}$ then started to drop down. Contrary to this, the relative density of the $4-6 \mathrm{~mm}$ fraction increased in the above-mentioned temperature range (Figure 5). In the coarser pellets, heat cannot be transferred into the inner part of the particles; therefore, calcination of foaming agent (limestone) did not take place appropriately. Only the glass melted near to the surface resulting in higher density (more compact structure).

The relative density diminished suddenly at $800^{\circ} \mathrm{C}$ from 92\% down to 39\% (Figure 4) when time increased from $5 \mathrm{~min}$ to 7.5 ; then the parameter was constant. Similar effect was observed in case of the other two size fractions (Figures 5 and 6). Therefore, it can be established that $800^{\circ} \mathrm{C}$ is a critical value (limit temperature) between porous and compact structures.

In the temperature range of $600-750^{\circ} \mathrm{C}$, a similar effect was found in all the three sizes; the relative density was fluctuating, but the rate of fluctuation was diverse. This difference range was $(-10 \%)-(+10 \%),(-5 \%)-(+25 \%)$, and $(-20 \%)-(+5 \%)$ in the $6-8 \mathrm{~mm}, 4-6 \mathrm{~mm}$, and $2-4 \mathrm{~mm}$ fraction, respectively.

Based on the results shown in Figures 4-6, sharp density decrease happens at $800^{\circ} \mathrm{C}$; this is represented by a steep curve section. However, gradual decrease can be seen at $850^{\circ} \mathrm{C}$ in all the three size fractions. It can be concluded that there is diversity in the trends in the lower temperature range $\left(600-750^{\circ} \mathrm{C}\right)$ and similarities are in the upper temperature zone $\left(800-900^{\circ} \mathrm{C}\right)$ in the investigated size fractions.

From Figures 3-6, it can be established that the ideal temperature and residence time from the viewpoint of density

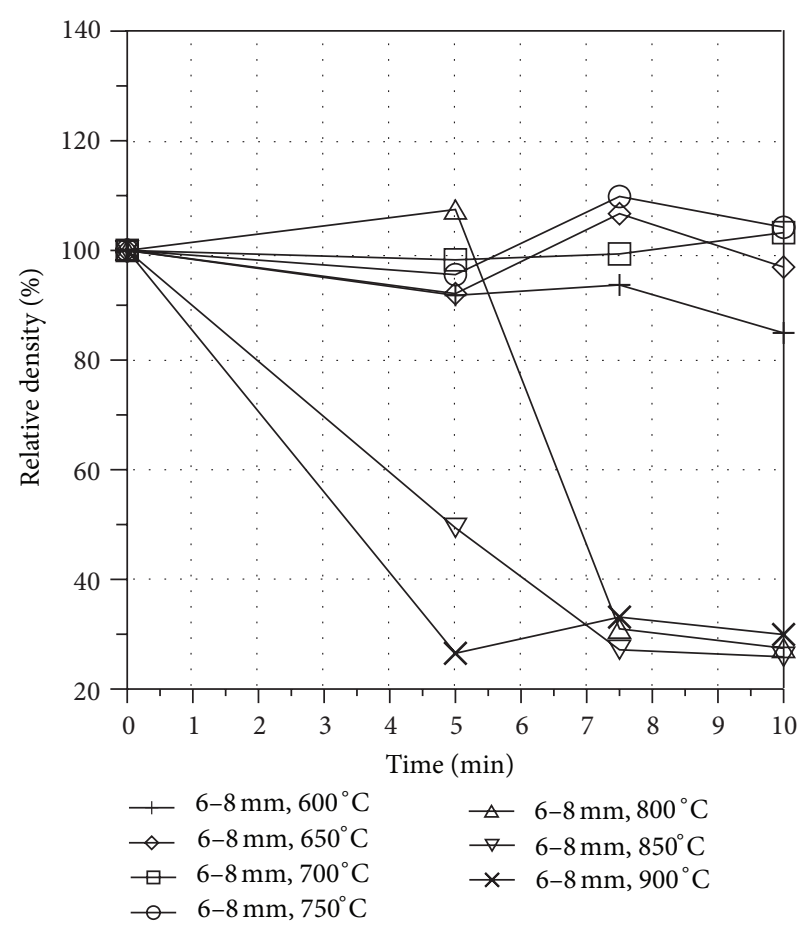

FIGURE 6: Change of relative density as function of residence time in case of size fraction $6-8 \mathrm{~mm}$.

decrease is $900^{\circ} \mathrm{C}$ and $5 \mathrm{~min}$, respectively, based on our experience, when relative density decreased dramatically by $\sim 70 \%$.

The viscosity and the surface tension of a silicate glass melt can be altered by the addition of quick lime, which is the residue from decomposition of the calcium. The modification of the viscosity of the glass melt is dependent on the miscibility of the oxide system. Therefore, it is feasible that the addition of small amounts (1-3 wt \%) of quick lime to the silicate glass melt will give rise to a small degree of phase separation which consequently results in the formation of a glass melt with high surface tension, but low viscosity, thus permitting a greater volume expansion of the molten mass carbonate [16].

Contrary to the results of Méar et al. [5, 6] where 30, 60 , and 90 min reaction time was used, we investigated the effect of shorter sintering time $(5 ; 7.5$, and $10 \mathrm{~min})$ to the foam properties resulted in an applicable foam structure. However, the sintering temperature range was similar.

4.2.2. Abrasion Loss. From application point of view, the mechanical stability of final product is of great importance. To investigate the abrasion resistance (rate of abrasion) of the foam, modified Deval tests were carried out as described previously. Since the initial pellet size does not reach the standard size fraction $(10-14 \mathrm{~mm})$, contrary to that the measurement was carried out using the manufactured pellets (2-4 mm, 4-6 mm, and 6-8 $\mathrm{mm}$ ) using 10 min residence time and then the product was sieved at $1.6 \mathrm{~mm}$ sieve aperture size, the evaluation used the mass of material finer $1.6 \mathrm{~mm}$. The 


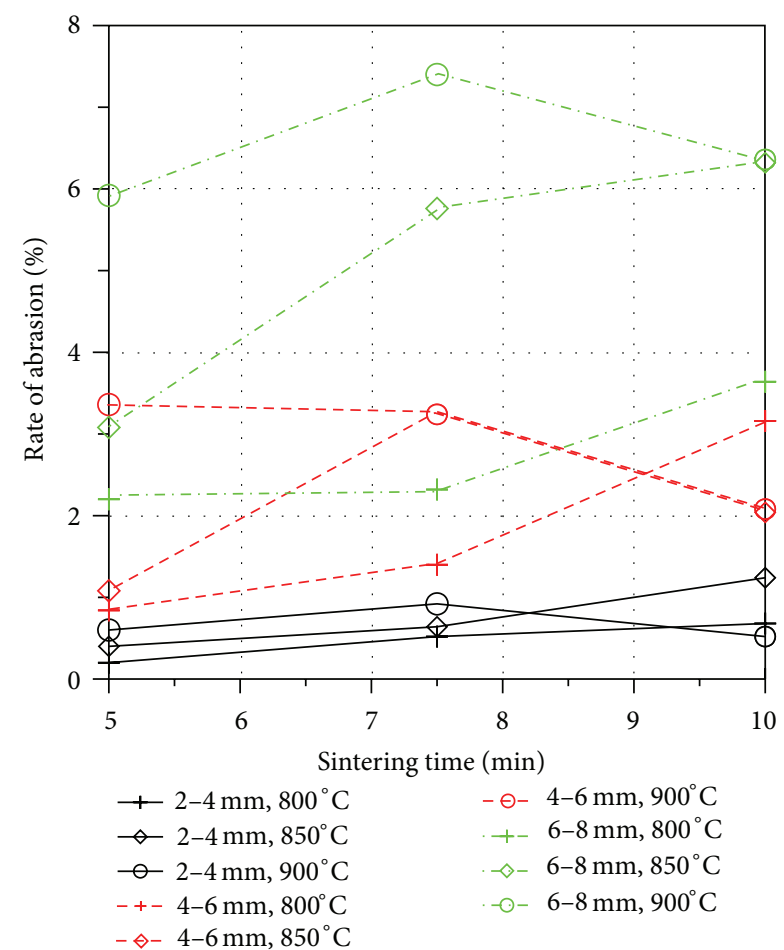

FIGURE 7: Abrasion of glass foam particles as function of sintering time.

TABLE 5: Inner cell size of glass foam manufactured at $900^{\circ} \mathrm{C}, 7.5 \mathrm{~min}$.

\begin{tabular}{lccc}
\hline & 1 & 2 & 3 \\
\hline Size range of pellet, mm & $2-4$ & $4-6$ & $6-8$ \\
Size interval of inner cells, $\mu \mathrm{m}$ & $100-250$ & $150-400$ & $200-900$ \\
\hline
\end{tabular}

results can be seen in Figure 7, where particles with real foam structure were tested, manufactured at 800,850 , and $900^{\circ} \mathrm{C}$.

It can be observed from Figure 7 that the rate of abrasion is considerably different depending on the particle size interval. The lowest abrasion rate $(0.2-1.3 \%)$ was found at the size fraction 2-4 mm. Higher fluctuation was observed in the other two fractions: $0.8-3.5 \%$ and $2.2-7.5 \%$ at $4-6 \mathrm{~mm}$ and $6-8 \mathrm{~mm}$, respectively. The relationship between particle size and abrasion resistance was revealed: the higher the glass foam particle size, the lower its resistance to abrasion stress (mechanical stability).

The effect of foaming temperature can be seen in Figure 7, the higher the temperature the higher the abrasion loss in all three particle size fractions of pellets at 5 and 7.5 min sintering time. However, this order changed at longer residence time $(10 \mathrm{~min})$; that is, the abrasion loss of foam prepared at $900^{\circ} \mathrm{C}$ will be lower than that of 800 and $850^{\circ} \mathrm{C}$ in size fractions $2-$ $4 \mathrm{~mm}$ and 4-6 $\mathrm{mm}$.

Mostly at the $7.5 \mathrm{~min}$ residence time, the rate of abrasion increased compared with results obtained at $5 \mathrm{~min}$ independently from size fraction and temperature. A further increase of residence time $(10 \mathrm{~min})$ resulted in lower rate of abrasion and higher mechanical stability again at $900^{\circ} \mathrm{C}$.
Based on the abrasion test result,s the $2-4 \mathrm{~mm}$ and $4-$ $6 \mathrm{~mm}$ are the suggested size fraction for manufacture of foam glass particles (Geofil-Bubbles).

4.2.3. Microstructure of Foam. The generated gas created cells in the particles which plays a role in volume increase and in mass decrease at 800,850 , and $900^{\circ} \mathrm{C}$. In order to investigate the size, shape and distribution of cells measurements were carried out with optical microscopy using Zeiss Imager.M2m (5x).

In the case of the experiment performed at $600^{\circ} \mathrm{C}$, a relatively homogeneous structure was prepared without porous structure, since the calcinations of $\mathrm{CaCO}_{3}$ did not start at that temperature. Contrary to this result, some cells are generated at $650^{\circ} \mathrm{C}$. However, nonmelted primary glass particles can be seen well in Figure 8(a).

Comparing the three size fractions, no significant difference in the size and number of cells can be detected in the microscopy images at $650^{\circ} \mathrm{C}$. The sizes of cells are generally in the range of $100-200 \mu \mathrm{m}$.

At $750^{\circ} \mathrm{C}$ a few number of bigger cells are detected; their size depends on the original size of pellet particles (Figure 8(b)). At smaller size, the size of cells does not exceed $200 \mu \mathrm{m}$; however, $300 \mu \mathrm{m}$ cells are generated at higher particle size. Micron size primary glass particles still can be seen.

In Figure 8(c), the microscopy image of pellets sintered at $800^{\circ} \mathrm{C}, 6-8 \mathrm{~mm}$ for $10 \mathrm{~min}$ is shown. The image represents well the structure generated at that temperature. The diameter and distribution of inner cells are higher than those of lower temperatures. Their size is in the range of $100-700 \mu \mathrm{m}$ depending on the pellet's size. Characteristic cell size is in direct proportional to the diameter of pellets. Due to the intensive melting of glass at $800^{\circ} \mathrm{C}$, the color of cooled sintered pellets is getting glassy like (molten glass phase), instead of the initial primary particles. Micron size glass particles cannot be seen at $800^{\circ} \mathrm{C}$; the homogeneous melted glass structure will be typical of the product mainly.

It can be observed that the color of pellets sintered at lower temperatures is darker, the number of cells is insignificant, and the diameter is smaller than that of produced at higher temperatures, especially at $850^{\circ} \mathrm{C}$. The considerable decrease of particle density established previously is supported by the microscopic images (Figure 8(d)).

It can be established that the increase of temperature and residence time results in higher number of cells in all three size ranges of pellets; their distribution was identical. The change of color and transparency shows similarities. The difference can be recognized only in the size of cells. The smaller the glass foam pellet's size, the smaller the average cell size (Table 5). Cell size generated at $900^{\circ} \mathrm{C}$ in different pellet size fraction can be seen in Figures 8(e) and 8(f).

Scanning electron microscopy (SEM) was used to take images on the samples for the visual observation of cell size and morphology. The micrographs were taken with a Zeiss EVO MA 10 Scanning Electron Microscope with 25 and 2000 magnification at the Faculty of Materials Science and 


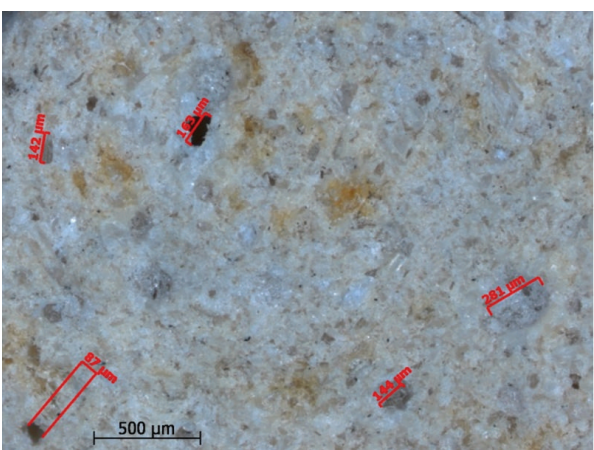

(a)

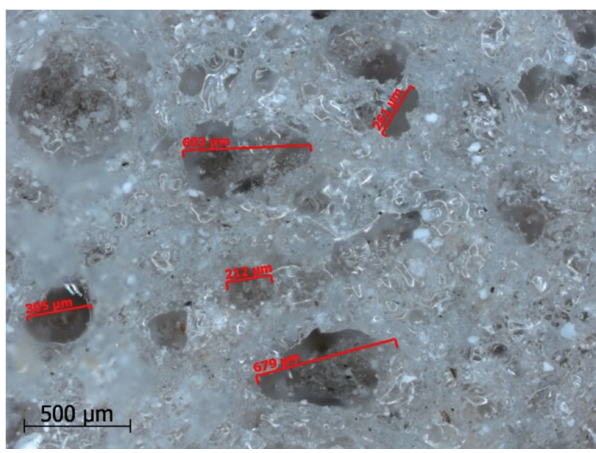

(c)

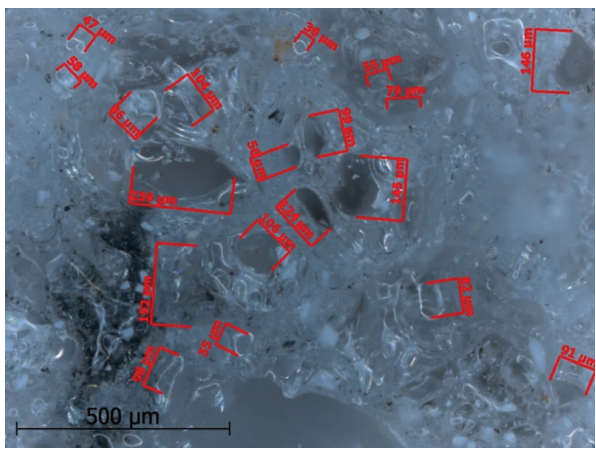

(e)

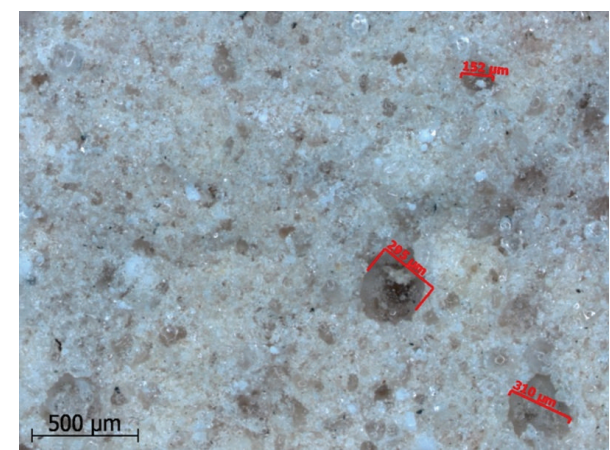

(b)

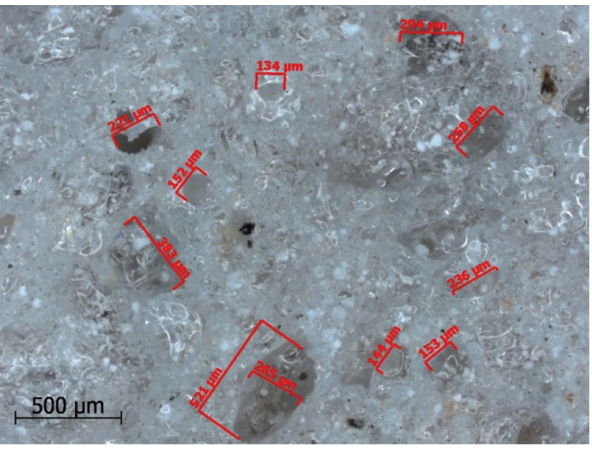

(d)

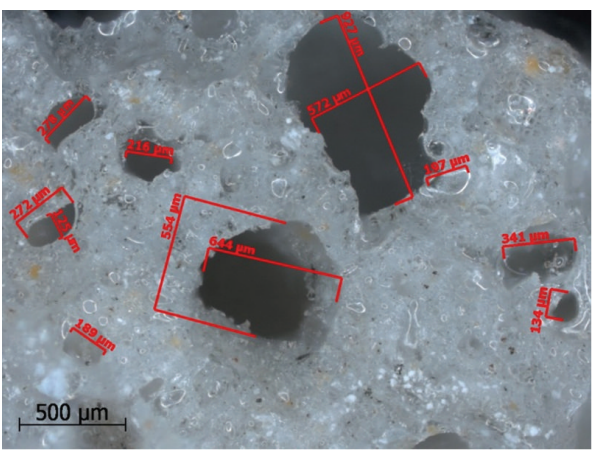

(f)

Figure 8: Microscopy images of sintered pellets (5x) at (a) $650^{\circ} \mathrm{C}$, (b) $750^{\circ} \mathrm{C}, 6-8 \mathrm{~mm}$, (c) $800^{\circ} \mathrm{C}, 6-8 \mathrm{~mm}, 10 \mathrm{~min},(\mathrm{~d}) 850^{\circ} \mathrm{C}, 6-8 \mathrm{~mm}, 5 \mathrm{~min}$, (e) $900^{\circ} \mathrm{C}, 7.5 \mathrm{~min} 2-4 \mathrm{~mm}$, and (f) $900^{\circ} \mathrm{C}, 7.5 \mathrm{~min} 6-8 \mathrm{~mm}$.

Engineering, University of Miskolc, Hungary. The results can be seen in Figure 9.

The appropriate foaming process leads to a precise density, corresponding to a certain volume of pores. This volume, however, may be distributed in a limited number of large pores or in a great number of small pores. Such different distributions can have a major influence on the performance and the properties of the glass foam. Generally, the lower the foam density, the lower the thermal conductivity (and the better the thermal insulation properties), without any evidence in the literature of dependence on cell size. On the other hand, the smaller the cell size, the higher the compressive strength of the product [16].

Fine-pored (pore diameter ca. $200 \mu \mathrm{m}$ ) and relatively homogeneous microstructure was achieved (Figure 9(a)).
Several openings between cells are clearly visible; the foam is open-celled. A more heterogeneous microstructure of the glass foam is found in Figure 9(b), moreover in Figure 9(c) where great coalescence cells formed near the pellet outer wall. However, as Méar et al. [5, 6] stated, less homogeneous structure and uniform cell size cannot be achieved using (CRT) glass, compared with metal foams. On the other hand, the cell wall inside the pellet (Figure 9(d)) was found to be relatively thin $(413.1 \mathrm{~nm})$.

In the range of 6-8 $\mathrm{mm}$, large cell size with irregular shape is created (only slight number). However, at the finer pellet particles the shape is more spherical-like than that of coarser size.

Investigating the distribution of cells, it can be stated that coarser cells are situated closer to the pellet's surface. In some 


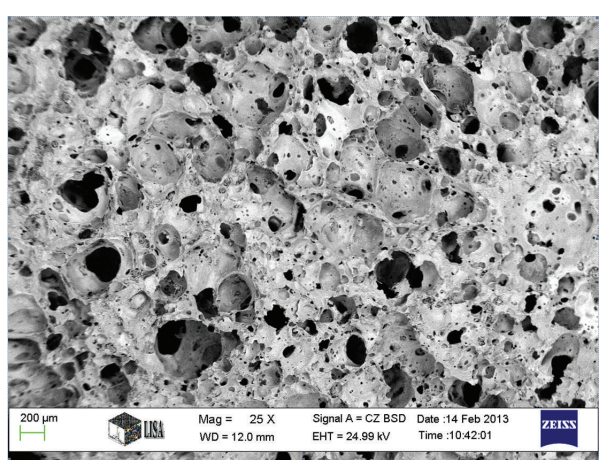

(a)

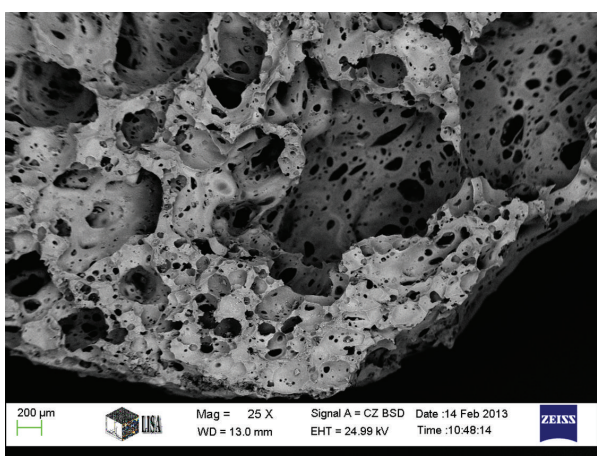

(c)

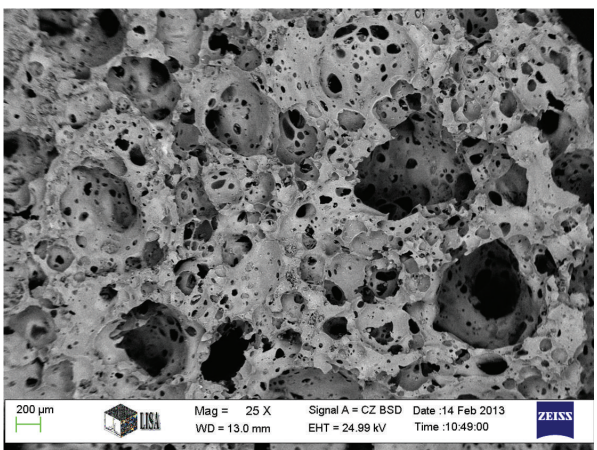

(b)

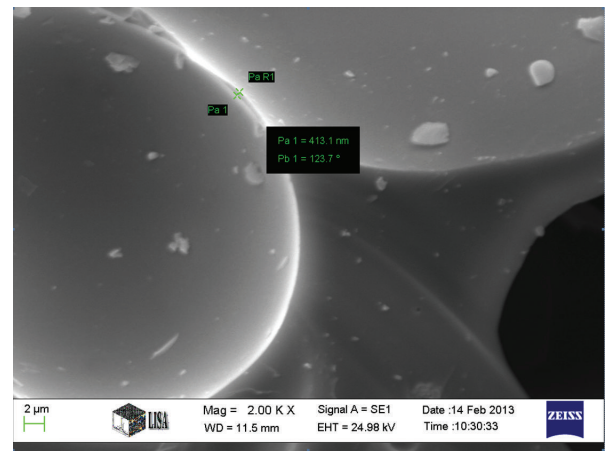

(d)

FIGURE 9: SEM micrographs of sintered pellets. (a) VI $1 \mathrm{c}-850^{\circ} \mathrm{C}, 5 \mathrm{~min}, 6-8 \mathrm{~mm}$, (b) VII $1 \mathrm{c}-900^{\circ} \mathrm{C}, 5 \mathrm{~min}, 6-8 \mathrm{~mm}$, (c) VII $1 \mathrm{c}-900^{\circ} \mathrm{C}$, $5 \mathrm{~min}, 6-8 \mathrm{~mm}$ : wall of the pellet, and (d) $\mathrm{V} 3 \mathrm{c}-800^{\circ} \mathrm{C}, 10 \mathrm{~min}, 6-8 \mathrm{~mm}$.

cases only a thin wall with few microns can be seen between the pellet's outer surface and the cell's inner surface, especially in the coarser size range of pellet $(6-8 \mathrm{~mm})$. It confirms the previously observed low mechanical stability of this size interval; that is, this thin wall can be broken easily by abrasion in the Deval drum.

When the temperature reaches $800^{\circ} \mathrm{C}$, the volume of the particles in addition to the number and size of the cells increases. Holes appear on the surface of the pellets due to the generated and escaped $\mathrm{CO}_{2}$ gas; namely, open cell structure is created. The pellets are very sensitive to the sintering temperature.

\section{Conclusions}

During the laboratory investigation of glass foam production, first the green pellets were classified into three size fractions: 2-4 mm, 4-6 mm, and 6-8 $\mathrm{mm}$. Preliminary pelleting tests were carried out. Mechanical stability of the product of systematic sintering experiments was determined, change of particle density was studied, and furthermore microstructures of the glass foam particles were monitored with optical microscopy.

Based on the experimental results, the following conclusions can be drawn.

(i) The particle density did not change significantly in the sintering temperature range of $600-750^{\circ} \mathrm{C}$ independently from the residence time and size range. (ii) Significant reduction in particle density was approached at $800^{\circ} \mathrm{C}$ after $7.5 \mathrm{~min}$; above these temperatures, $850^{\circ} \mathrm{C}$ and $900^{\circ} \mathrm{C}$ the density diminished even after $5 \mathrm{~min}$.

(iii) Evaluating the modified Deval abrasion test results the highest abrasion was observed at the coarsest size $(6-8 \mathrm{~mm})$ range $(2.2-7.2 \%)$ and the smallest abrasion was found at the finest $(2-4 \mathrm{~mm})$ interval $(<1 \%)$.

(iv) Due to the increasing temperature, homogeneous, porous glass-like structure was forming until certain value $\left(850^{\circ} \mathrm{C}\right)$. After this temperature, the cells are getting coalesced creating coarse cells with irregular shape.

(v) The higher the pellet's diameter the coarser the inner cell size closer to the particle surface, resulting in weaker structure and higher abrasion to mechanical stress.

(vi) The optimal settings for foam glass manufacture taking into account the mechanical stability and particle density are determined: $800^{\circ} \mathrm{C}$ temperature and $7.5 \mathrm{~min}$ residence time are suggested for ideal foam characteristics (thermal insulation) using the size fraction $4-6 \mathrm{~mm}$. In this case, density reduced to $600-900 \mathrm{~kg} / \mathrm{m}^{3}$. The best mechanical stability was approached using the pellet size $2-4 \mathrm{~mm}$ at $800^{\circ} \mathrm{C}$; these can be applied as aggregate for producing lightweight concrete (LWAC). 
(vii) Generally, it can be concluded that the production of glass foam is a good feasible way to recycle CRT glass wastes.

(viii) It is planned to continue the research work using other kinds of glass and other silicate bearing byproducts or wastes to improve material properties.

\section{Acknowledgments}

This work was carried out as part of the TÁMOP-4.2.1.B10/2/KONV-2010-0001 Project in the framework of the New Hungarian Development Plan. The realization of this project is supported by the European Union and cofinanced by the European Social Fund. Furthermore, the authors greatly appreciate the SEM analyses of Árpád Kovács.

\section{References}

[1] C. H. Lee, S. L. Chang, K. M. Wang, and L. C. Wen, "Management of scrap computer recycling in Taiwan," Journal of Hazardous Materials, vol. A73, pp. 209-220, 2000.

[2] E. Bernardo, G. Scarinci, and S. Hreglich, "Mechanical properties of metal-particulate lead-silicate glass matrix composites obtained by means of powder technology," Journal of the European Ceramic Society, vol. 23, no. 11, pp. 1819-1827, 2003.

[3] C. Corcoran, "Communication in Western Electronic Product Stewardship Initiative (WEPSI)," Multi-Stakeholder Meeting no 3, Portland, Ore, USA, December 2001.

[4] F. Andreola, L. Barbieri, A. Corradi, I. Lancellotti, R. Falcone, and S. Hreglich, "Glass-ceramics obtained by the recycling of end of life cathode ray tubes glasses," Waste Management, vol. 25, no. 2, pp. 183-189, 2005.

[5] F. Méar, P. Yot, M. Cambon, and M. Ribes, "The characterization of waste cathode-ray tube glass," Waste Management, vol. 26, no. 12, pp. 1468-1476, 2006.

[6] F. Méar, P. Yot, and M. Ribes, "Effects of temperature, reaction time and reducing agent content on the synthesis of macroporous foam glasses from waste funnel glasses," Materials Letters, vol. 60, no. 7, pp. 929-934, 2006.

[7] M. Chen, F. S. Zhang, and J. Zhu, "Lead recovery and the feasibility of foam glass production from funnel glass of dismantled cathode ray tube through pyrovacuum process," Journal of Hazardous Materials, vol. 161, no. 2-3, pp. 1109-1113, 2009.

[8] N. Menad, "Cathode ray tube recycling," Resources, Conservation and Recycling, vol. 26, no. 3-4, pp. 143-154, 1999.

[9] D. Kim, M. Quinlan, and T. F. Yen, "Encapsulation of lead from hazardous CRT glass wastes using biopolymer cross-linked concrete systems," Waste Management, vol. 29, no. 1, pp. 321328, 2009.

[10] "New approach to cathode ray tube (CRT) recycling," Report prepared by ICER for DTI GW-12.10-130, 2003, http:// www.bis.gov.uk/files/file30300.pdf.

[11] Y.-C Seo, S.-J Cho, J.-S Lee, B.-S Kim, and C. Oh, "A study on recycling of CRT glass waste," in Proceedings of the International Conference on Environment and Industrial Innovation IPCBEE, vol. 12, IACSIT Press, Singapore, 2011.

[12] L. Hoffmann, "Process for (especially) waste of glass materials to produce closed pore-structured silicate-foam, and product," Patent no. HU 224808 B1, Geofil-Bubbles.
[13] Z. Józsa and R. Nemes, "Recycled glass aggregate for lightweight concrete," Journal of Concrete Structures, pp. 41-46, 2002.

[14] G. Mucsi, "Fast test method for the determination of the grindability of fine materials," Chemical Engineering Research and Design, vol. 86, no. 4, pp. 395-400, 2008.

[15] I. Csiszár, Optimization of pelleting process during CRT waste based glass foam production [Diploma thesis], University of Miskolc, 2010.

[16] M. Scheffler and P. Colombo, Cellular Ceramics: Structure, Manufacturing, Properties and Applications, WILEY-VCH, Weinheim, Germany, 2005.

[17] H. Hojaji, "Development of foam glass structural insulation derived from fly ash," Materials Research Society Symposium Proceedings, vol. 136, pp. 185-206, 1988.

[18] G. Brusatin and G. Scarinci, "Sintered glass-ceramics from waste inert glasses," in Proceedings of the 4th International Congress Valorisation and Recycling of Industrial Wastes (VARIREI '03), L’Aquila, Italy, 2003. 

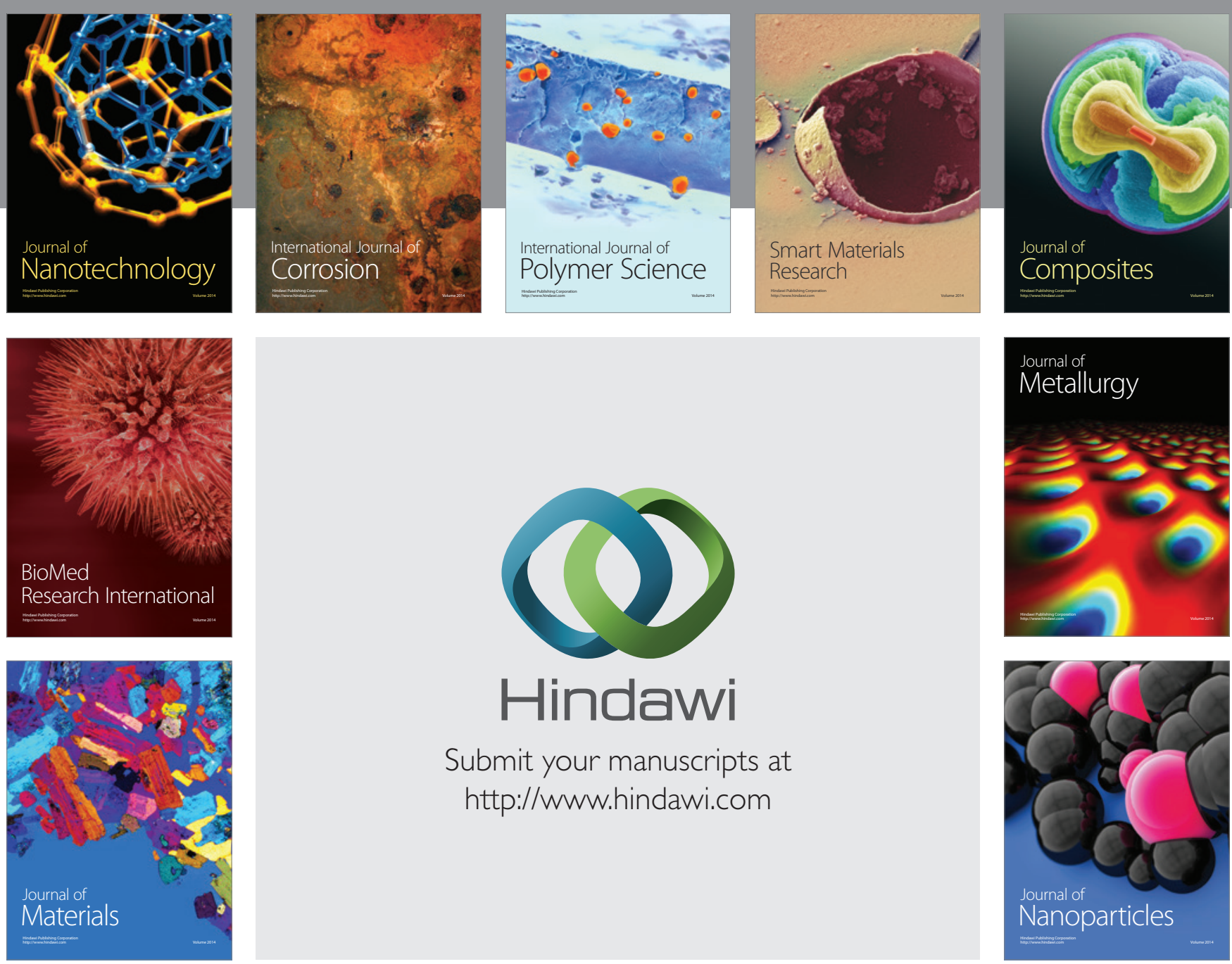

Submit your manuscripts at http://www.hindawi.com
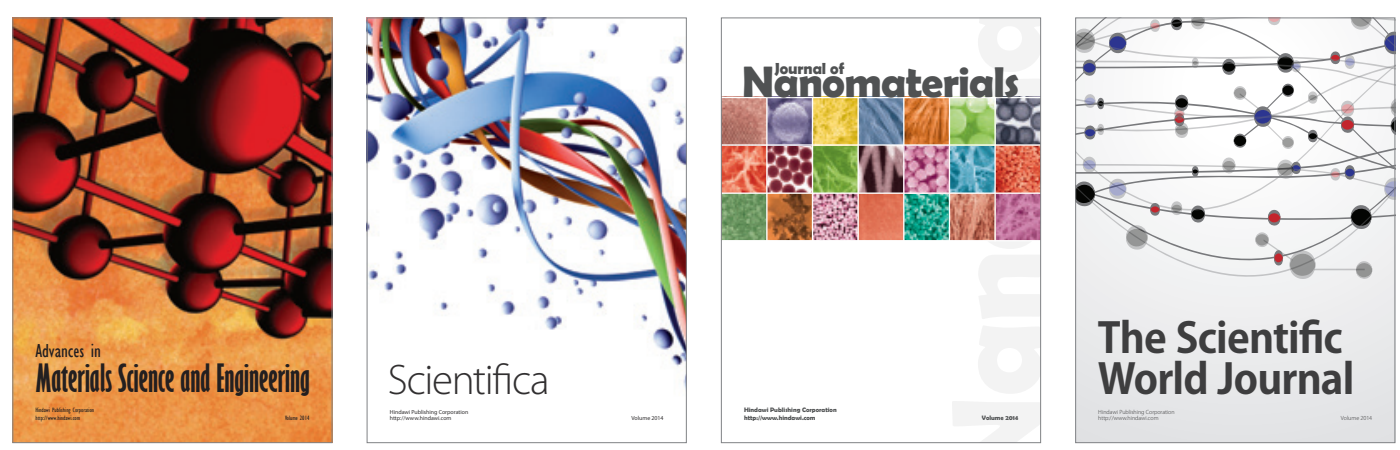

\section{The Scientific World Journal}
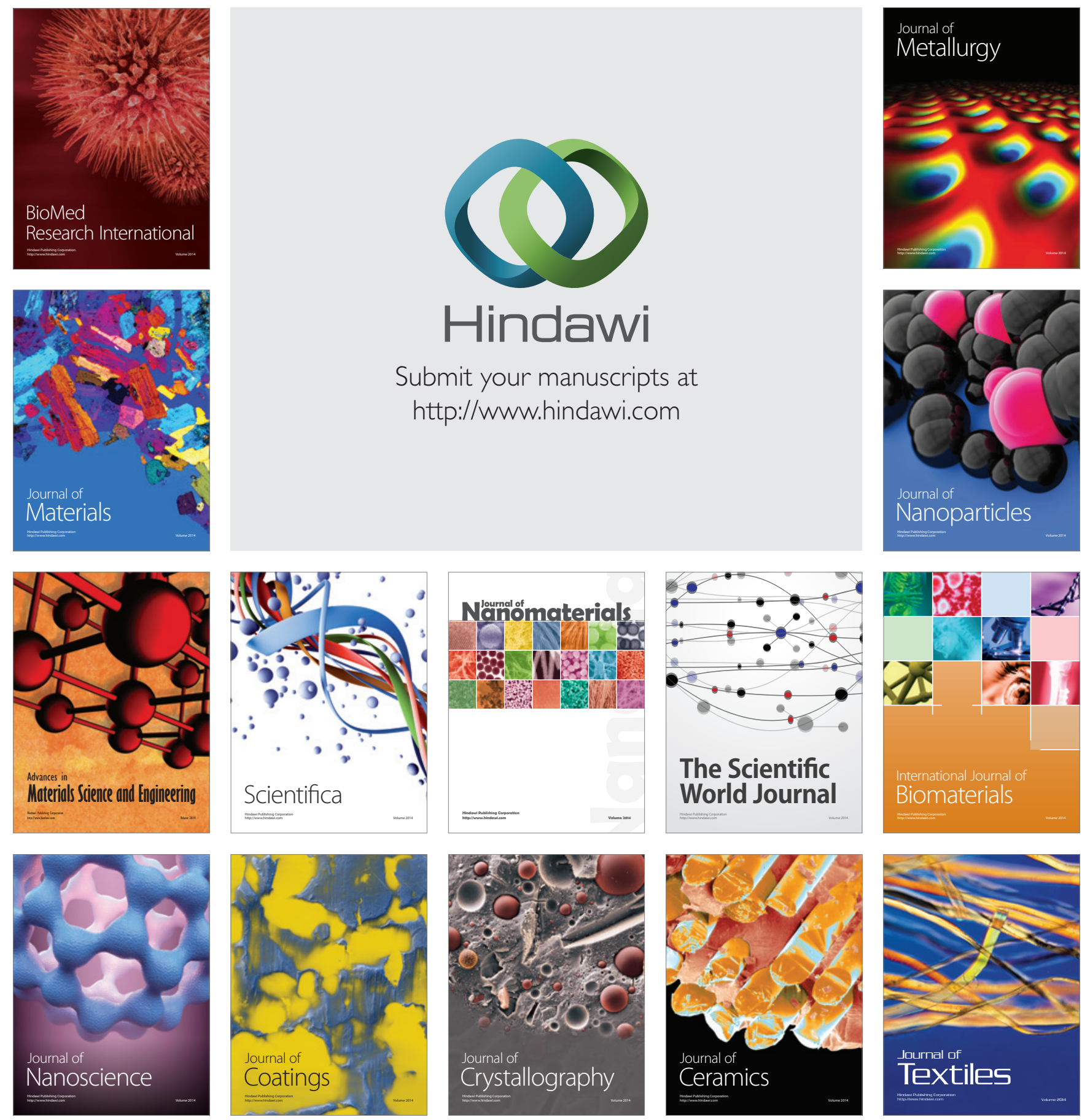